\title{
The Resistance of Bean Yellow Mosaic Virus (BYMV) in Faba bean (Vicia faba L.) with Diallel Analysis
}

\author{
Mohamed Abd El-Hamid El-Bramaw (Corresponding Author) \\ Agronomy Department, Faculty of Agriculture \\ Suez Canal University, 41522 Ismailia, Egypt \\ E-mail: el_bramawy71@hotmail.com
}

Essam Kamal Fahmy El-Beshehy

Agricultural Botany Department, Faculty of Agriculture

Suez Canal University, 41522 Ismailia, Egypt

Received: May 16, 2010 Accepted: January 4, 2011 doi:10.5296/jbls.v2i1.588

\begin{abstract}
Bean yellow mosaic virus (BYMV) has been recognized as one of the major economic disease and reduced a considerable destructive in seed yield, particularly, when plants were infected at the beginning stage of faba bean growing regions of Egypt. Little genetic information is available on the resistance of Vicia faba to BYMV disease. Hence, this study was conducted to determine the relative importance of general (GCA) and specific (SCA) combining ability, maternal and non-maternal reciprocal effects on resistance to BYMV in selected faba bean genotypes through mechanical transmation of BYMV. A complete diallel mating scheme including reciprocals of six faba bean genotypes varied in their resistant and susceptible to BYMV were evaluated in the Experimental Farm, Faculty of Agriculture, Suez Canal University, Ismailia, Egypt during two seasons (2008/09 \& 2009/010). The results show that the combining ability analysis revealed that both additive and non additive gene effects were present at this juncture and played a major role in the genetic resistance to BYMV. The crosses between the resistant and susceptible faba bean genotypes showed intermediate disease reaction to the BYMV, suggesting a polygenic system of resistance to BYMV. Significant maternal and specific reciprocal differences among the parents and their crosses indicated that maternal inheritance is involved in the reaction of faba bean genotypes to BYMV. Also, significant genotype $\mathrm{x}$ years interaction suggested a deficient in stability in the development of virus pathogen on faba bean plants. Therefore, recurrent selection would be appropriate for accumulating genes for resistance to BYMV in $V$. faba and progeny
\end{abstract}


performance may be based on their parent's performance per se.

Kewords: Bean yellow mosaic virus, BYMV, Combining ability, Diallel, Disease, Faba bean, Resistance.

\section{Introduction}

Faba bean, Vicia faba L, is considered as one of the most important food legumes in Egypt. It is the earliest domesticated food legumes, which believed to be originated in the West Asia Mediterranean region (Bond Et Al. 1994). It plays a major role in the Egyptian diets as a source of protein (Hassan, 1996). V. faba is grown mainly by poor farmers, many of them are man and women owner with many children. For these people the crop is vital for both food security and income generation.

In spite of the importance of faba bean crop as a famine and food security plant, it is constantly threatened by production constraints such as drought, low yielding local cultivars, lack of good quality planting materials, land tenure, pests and diseases...etc. (Ibrahim And Nassib, 1979; Hawtin Et At., 1983; Tivoli Et Al., 1988 and Abdalla \& Darwish, 2002). However, under certain environmental conditions, it can improve soil fertility and reduce the incidence of weeds, diseases and pests, when grown in rotation with other field crops (Mwanamwenge Et. Al., 1998).

Although of all the constraints, diseases found on faba bean are considered of the most destructive and causes considerable losses in its yield which estimated at over $50 \%$. (El-Hosary Et Al., 1998; Bouhassan Et Al., 2004; Awaad Et Al., 2005; El-Bramawy \& Abdul Wahid, 2005 and El-Bramawy \& Shaban, 2010). Among these diseases constraints, virus diseases, so many diseases can affect faba bean plants which considered a serious worldwide problem (Jones, 1997 and El-Tahlawy, 2005). Infection by certain viruses causes significant economic losses and yield reduction (estimated by $30 \%$ on susceptible cultivars of faba bean cultivars (Khalil \& Erskine, 2001). Viral diseases have an important status because they not only cause direct damage to the host, but also predispose the plant to secondary invaders (Beute, 1970 and Mahgoub Et Al., 1997). Among faba bean viruses, bean yellow mosaic virus (BYMV) consider as one of the most devastating viruses affecting faba bean plants in Egypt (Allam Et Al., 1984; Bashir Hmpton, 1996; El-Beshehy, 1999; Khatab, 2002; Elbadry Et Al., 2006 and Radwan Et Al., 2008). BYMV (family Potyviridae, genus Potyvirus) is an aphid transmitted virus in non-persistent mode and has a wide host range (Jones \& Mclean, 1989 and Jones, $2004 \&$ 2005). BYMV not only infects legumes causing yield losses, but also affects the horticulture industry by infecting gladiolus, one of the top six flowers of the export market (Anonymous, 1997). Systemic symptoms caused by BYMV infection do not kill faba bean plants, but have the potential to spread faster and further into the crop, causing greater overall yield reduction, despite inducing milder symptoms (Cheng Et Al., 2002 and Sidaros Et Al., 2006).

In spite of all the widespread distribution of bean yellow mosaic virus with a high incidence of the virus (BYMV) across the countries in world wide, the progress made in resistance breeding to BYMV is rarely comparing to other diseases. Therefore, it should be taken into 
consideration in the breeding programme (Jones \& Mclean, 1989). The spotlight has, therefore, shifted to host plant resistance. It is acknowledged that resistant faba bean varieties could potentially form the basis of sustainable management strategies for faba bean virus diseases (Bashir Et Al., 2002). The selection of faba bean resistant varieties and continuous breeding programme for disease resistance appears to be the efficient means of controlling the disease considering (BYMV).

Although, little work has been done on resistance to BYMV and determination of mode on inheritance. So, it is important to continue in this direction in order to cover and confirm obtaining resistance varieties of faba bean crop. Such studies in these areas will assist the plant breeders in formulating an efficient strategy for incorporating the resistant genes into high yielding improved and stable varieties of the crop considering. Therefore, the overall objective of the present practical work is to contribute to the development of stable bean yellow mosaic virus resistance in faba bean. The specific objective of this study was to evaluate the relative importance of general (GCA) and specific (SCA) combining ability for resistance to BYMV through mechanical transmation of BYMV disease.

\section{Materials \& Methods}

\subsection{BYMV isolation and identification}

Twenty night samples of faba bean plants exhibiting venial yellowing, followed by obvious faba beans develop veinal yellowing, followed by obvious green or yellow mosaic vein banding with yellowish line patterns. Symptoms which are more prominent on young leaves were collected from eight different fields of Ismailia Governorates. These samples were checked serologically against Bean yellow mosaic virus (BYMV), Alfalfa mosaic virus (AMV), Broad bean mottle virus (BBMV), Broad bean true mosaic virus (BBTMV) and Bean leaf roll virus (BLRV). Plant samples which gave positive reaction in the indirect ELISA test with BYMV as reported by Hobbs Et Al., 1987.

These antibodies were obtained from International Center for Agricultural Research in the Dry Areas (ICARDA). Plant extracts were prepared by grinding thoroughly the tissues $(0.5 \mathrm{gm})$ in the presence of $450 \mu \mathrm{l}$ extraction buffer to reach a dilution $1 / 10$. The microplates were loaded by $100 \mu 1$ in each well. Plats were then incubated for 1 hour at $37^{\circ} \mathrm{C}$. During incubation cross absorption for the crude primary antiserum was prepared with healthy potato leaves sap according to the dilutions $1 / 100,1 / 5000$ and $1 / 10000$.

The microplates were unloaded and washed 3 times with PBS-Tween allowing 3 minutes soaking for each wash. The cross- absorbed $100 \mu \mathrm{l}$ of antiserum was loaded to each well and the plates were incubated at $37^{\circ} \mathrm{C}$. for 90 minutes. The plats were unloaded and washed with PBS-Tween as mentioned above. The secondary antiserum $100 \mu 1$ (anti rabbit - anti goat enzyme conjugate) diluted $1 / 1000$ was loaded to each well and the plates were incubated at $37^{\circ} \mathrm{C}$ for 60 minutes. Just before use, 2 tablets of sigma 4-nitrophenylphosphate were dissolved in 21 milliliter of substrate buffer. The colour of the reaction was observed.

Plant samples which gave positive reaction in the indirect ELISA test with BYMV were separated and the extracted diluted sap for sample was used to inoculate the following faba 
bean Giza $461 \mathrm{cv}$. prepared for BYMV. The inoculum was prepared from BYMV infected top faba bean leaves, ground in a mortar containing $0.1 \mathrm{M}$ phosphate buffer, $\mathrm{pH} 7.0$ (1:2 w: v_1). The homogenate was filtrated through two layers of muslin, and the leaves of healthy plants were dusted with carborundum and rubbed gently with a cotton swab previously dipped into the suspension of virus inoculum. The faba bean plants were kept at $100 \%$ water-holding capacity.

\subsection{BYMV inoculation with cultivar sours (Giza $461 \mathrm{cv}$.)}

Faba bean of Giza $461 \mathrm{cv}$. were used as an indicator host cultivar for test inoculum of the BYMV. Giza $461 \mathrm{cv}$. seeds were sown in a mixture of sand and clay (1: $\left.2 \mathrm{v} \mathrm{v}_{-} 1\right)$ in plastic pots $(10 \mathrm{~cm}$ in diameter) in separated growth chambers under a photoperiod of $12 \mathrm{~h}$ (PAR 400 -700 mmolm_2 s_1). Temperatures degree through day and night were 22 and $17^{\circ} \mathrm{C}$, respectively and the relative humidity was approximately $70 \%$. The infected faba bean plants were kept at 100\% water-holding capacity. This cultivar (Giza $461 \mathrm{cv}$.) was used in earlier studied as an infected propagative host with BYMV by El-Beshehy (1999) and Radwan Et Al. (2008).

Preparation of inoculum of bean yellow mosaic virus was prepared from BYMV infected top faba bean leaves ( Giza $461 \mathrm{cv}$.), ground in a mortar containing $0.1 \mathrm{M}$ phosphate buffer, $\mathrm{pH}$ 7.0 (1: 2 wv_1). For artificial mechanical translation (AMT), the homogenate was filtrated through two layers of muslin, and the leaves of healthy plants were dusted with carborundum and rubbed gently with a cotton swab previously dipped into the suspension of virus inoculum.

\subsection{Background of parental material}

The parents for the current study were selected from previous evaluation which was carried out through a breeding program in the Agronomy Dept, Faculty of Agricture, Suez Canal University, Ismailia, Egypt. This breeding program was started since few years ago (2003 \& 2004) through earlier work which was done by El-Bramawy \& Abdul Wahid (2005). Six faba bean parents were selected depend on the earliness, seed yield (g/plant) and degrees of resistance to some diseases at the Experimental field, Fac. of Agric., Suez Canal Univ., Ismailia, Egypt. In addition, some of them (six parents) also evaluated with reaction of BYMV infection previously by El-Beshehy (1999). These parents were chosen as resistant, moderately resistant and susceptible varieties according the former evaluation. Parental names, pedigree, earliness, seed yield (g/plant) and description symptoms were presented in Table (1).

\subsection{Parental selection and their crosses}

To conform the previous evaluation done in the field, green house experimental at the Agricultural Botany Dept., Fac. of Agric., Suez Canal Univ., Ismailia, Egypt was done to re-evaluate the interaction of the six faba bean parent's plants with BYMV disease under artificial infection conditions of the BYMV considering through season 2007/08. Table (2) shows the obtained results of the interaction between the six faba bean parent's plants with BYMV disease. These results exhibited the main percentage of infection incidence and 
severity of the infection for the six faba bean parent's genotypes in comparing to their control.

\subsection{Hybridization modeling and obtaining the crosses}

According to determination of selected the six faba bean parents, a full diallel mating scheme $(6 \times 6)$, where all possible combination in two way among parents was made by hand pollination in season 2007/08 at the Experimental field, Fac. of Agric., Suez Canal Univ., Ismailia, Egypt. The seeds were made available by helping staff technician in Agronomy Dept, of the same University. The crosses obtained through the hybridization model were 30 crosses (hybrids and reciprocal).

\subsection{Green house experiment design for interaction between crosses and BYMV}

The seeds of faba bean crosses (30) with their respective parents (6) were planted in pots (40 $\mathrm{cm}$ in diameter) by rate of 10 seeds per pot. A randomized complete block design (RCBD) with three replicates was used. Each block contained the all pots crosses (30 hybrids and reciprocal) and their parents (six parents). Each plot consisted of one pot with 10 seeds per cross and also one pot per 10 seeds of each parent, for the $F_{1}$ 's and their respective parents, respectively. This green house experiment was repeated two times through successive seasons 2008/09 and 2009/010 at Agricultural Botany Dept., Fac. of Agric., Suez Canal Univ., Ismailia, Egypt.

\subsection{Infection by the inoculume of BYMV}

Each of 6 parent and their 30 crosses were evaluated at reaction with BYMV infection using, the interaction faba bean genotypes with BYMV inoculum by artificial mechanical translation (AMT), which mentioned before. Three weeks from the inoculation by BYMV inoculum, leave symptoms were observed. Non-inoculated pots of faba bean generations plants (control) were growth parallel with the inoculated plants of faba bean, where used as a control. Neither fertilizer nor herbicide was applied during the experiment working, where only hand weeding was done when necessary.

\subsection{Calculation of BYMV infection percentage and severity of disease}

The parents (6) and their $F_{1}$ 's hybrids and reciprocals (30) were evaluated and examined for disease severity as individual plants in each pot relation to total plants in each one. Table (2) counting and calculating the numbers of infected faba bean plants by BYMV as a percentage of BYMV disease incidences using the parameters rating scale. The disease severity (DS) method was adopted as per Yang et al. (1996).

$$
\begin{gathered}
\text { DS }(\%)=(\text { disease grade } \quad x \quad \text { number of plants in each grade }) /(\text { total } \\
\text { number of plants } x \text { highest disease grade }) \times 100
\end{gathered}
$$

\subsection{Genetic parameters and Statatistical analysis}

Faba bean genotypes were partitioned into variations due to parents and crosses using the procedure of Statatistical Analysis System (SAS). The analysis of variance for the crosses 
was based on Griffing's method 2, model for fixed genotypes (Griffing, 1956) and the linear model (Singh \& Chaudhary, 1977). The analysis was performed on individual environments (years/ two seasons) using the diallel-SAS programme written by Kang (1994) and a combined analysis over environments (years) using the diallel-SAS programme written by Zhang \& Kang (1997).

The general linear model for individual environments/years was

$$
\text { Yijk }=\mu+g i+g j+s i j+r i j+b k+\mu i j k
$$

where; Yijk was the response of the kth observation in the ith environment of the plant; $\mu$ was general mean; gi the general combining ability (GCA) of the ith parent; gj the general combining ability (SCA) of the jth parent; sij the specific combining ability associated with the ith and jth cross; rij the reciprocal effects associated with ijth cross. bk the effect of the kth replicate and $\mu \mathrm{ijk}$ is the error associated with each observation.

The general linear model for the combined analysis was

$$
\text { Yijkl }=\mu+g i+g j+s i j+l k+b l(k+g l i k+g l j k+s l i j k+m i j l)
$$

In this model, Yijkl was the observed response to BYMV across the two seasons; $\mu$, gi, gj and sij and its partitions mi and nj were for the individual season analysis. The effect $\mathrm{k}$ was the effect of the kth season; bl (k) the effect of the lth replicate within the kth season. The effect glik was the general combining ability of the ith parent in the season; gljk the general combining ability of the jth parent in the kth environment and slijk the specific combining ability associated with the ijth cross in the season. Genetic components of the variation associated with GCA and SCA effects were estimated from their respective expected means squares. The ratio of these components was computed to estimate the relative importance of GCA in predicting progeny performance. The GCA and SCA effects and their standard errors were estimated according to Singh \& Chaudary (1977). Pearson correlations using line and top cross means were calculated to compare line and top cross.

\section{Results}

The analysis variance of the modeling complete diallel fashion scheme $(6 \times 6)$, which includes the parental faba bean genotypes (Tribe White, Giza 3, Giza 714, Giza 429, Sakha 1 and BPL 710) shows in Table 3. There were variations $(\mathrm{p}<0.05)$ among the tested faba bean genotypes for BYMV disease and seasons or years in the combined analysis. Moreover, the contrast parent $\mathrm{x}$ crosses (the test for average heterosis) was significant for both of the individual year/season and combined seasons as presented in Table (3).

Table 3 showes the Griffing analysis of variance for the crosses (hybrids) exhibited significant general combining ability (GCA), specific combining ability (SCA), maternal (M) and specific reciprocal $(\mathrm{R})$ effects in both the individual year/season and in combined.

The ratio $\delta^{2} \mathrm{GCA} / \delta^{2} \mathrm{SCA}$ which presented in Table (3) were more than unity (1) for the resistance to bean yellow mosaic virus. On the other side, the combination interaction i.e. parents $\mathrm{x}$ crosses $(\mathrm{P} x \mathrm{C})$, crosses $\mathrm{x}$ years $(\mathrm{C} \mathrm{x} \mathrm{Y})$, general combining ability $\mathrm{x}$ years (GCA $\mathrm{x}$ 
$\mathrm{Y}$ ), specific combining ability x years (SCA x Y), reciprocal, environmental, crosses $\mathrm{x}$ years (REC x Y), maternal $x$ year $(\mathrm{M} \mathrm{x} \mathrm{Y)}$ effects were also significant for the resistance to BYMV disease. While, the maternal effects among the parents were significant just as the specific reciprocal $(\mathrm{p}<0.01)$ as shown in Table (3).

Table 4 presents the estimates of GCA effects of each parent for total number of faba bean plants which resistance to bean yellow mosaic virus (BYMV). Sakha 1 cultivar behaved the same trend approximately as the resistant cultivar BPL 710. These both cultivars scored $-3.91^{* *},-5.14 * *,-4.18^{* *}$ (BPL 710) and $-1.64^{*},-2.16^{* *}-3.08^{* *}$ (Sakha 1) in seasons 2008/09, 2009/010 and their combined, respectively. On the other hand, the susceptible cultivar (Giza 2) used in this study exhibited significant and positive GCA in all the conditions, first (2008/09), second (2009/010) season and their respective combined (Table 4). However, the moderately susceptible i.e. Giza 429 and Giza 714 had significant and positive GCA effects in the first season, 2008/09 (3.64**) and also in the second season, 2009/010 $(1.31 *)$.

Regarding to the estimates of least square mean, table (5) shows the specific combining ability effects and reciprocal effects for $6 \times 6$ diallel analysis of resistance to bean yellow mosaic virus (BYMV) of faba bean. The crosses and their reciprocals manifested varying in degree of resistance to BYMV in each of the first, second and the combined season. The crosses e.i. $\mathrm{P}_{1} \times \mathrm{P}_{6}$ (Tribe White $\mathrm{x}$ BPL 710) and $\mathrm{P}_{3} \times \mathrm{P}_{6}$ (Giza714 x BPL 710), possessed the negative values and significant SCA effects in both seasons and their combined. The values of these SCA effects were -3.01*, $-3.28^{*}-3.89^{* *}\left(\mathrm{P}_{1} \times \mathrm{P}_{6}\right)$ and $-3.60 *,-3.54 *-4.18^{* *}\left(\mathrm{P}_{3} \mathrm{x}\right.$ $\mathrm{P}_{6}$ ) in 2008/09, 2009/010 season and their respective combined, in respectively (Table 5). Negative specific reciprocal effects for resistance to BYMV were significant for crosses $\mathrm{P}_{6} \mathrm{x}$ $\mathrm{P}_{1}$ (BPL $710 \times$ Tribe White), $\mathrm{P}_{6} \times \mathrm{P}_{2}$ (BPL $710 \times$ Giza 3), $\mathrm{P}_{6} \times \mathrm{P}_{3}$, (BPL $710 \times$ Giza714), $\mathrm{P}_{6} \mathrm{x}$ $\mathrm{P}_{4}$ (BPL $710 \times$ Giza 429) and P6 x $\mathrm{P}_{5}$ (BPL $710 \times$ Sakha 1), in season 2008/09 and 2009/010 and their respective combined (Table 5).

On the other hand, the crosses which used the parent Giza $3\left(\mathrm{P}_{2}\right)$ as a susceptible cultivar such as $\mathrm{P}_{1} \times \mathrm{P}_{2}, \mathrm{P}_{2} \times \mathrm{P}_{3}, \mathrm{P}_{2} \times \mathrm{P}_{4}$ and $\mathrm{P}_{2} \times \mathrm{P}_{5}$ (SCA effects) and $\mathrm{P}_{3} \times \mathrm{P}_{2}, \mathrm{P}_{4} \times \mathrm{P}_{2}$, and $\mathrm{P}_{5} \times \mathrm{P}_{2}$ (SCA reciprocal effects) showed positive and significant values of SCA effects and their reciprocal effects, respectively through seasons 2008/09, 2009/010 and their combined. These SCA effects were 6.31**, 3.87*, 5.11** $\left(\mathrm{P}_{1} \times \mathrm{P}_{2}\right), 6.21^{* *}, 8.14 * *, 4.59 * *\left(\mathrm{P}_{2} \times \mathrm{P}_{3}\right),-1.64,2.00^{*}$, -3.01* $\left(\mathrm{P}_{2} \times \mathrm{P}_{4}\right)$ and 4.11**, 6.17**, 5.12** $\left(\mathrm{P}_{2} \times \mathrm{P}_{5}\right)$, while SCA reciprocal effects were $2.98^{*}, 1.99,3.01^{* *}\left(\mathrm{P}_{3} \times \mathrm{P}_{2}\right), 2.01,1.38,1.84\left(\mathrm{P}_{4} \times \mathrm{P}_{2}\right)$ and $2.58^{*}, 6.07^{* *}, 4.36^{* *}\left(\mathrm{P}_{5} \times \mathrm{P}_{2}\right)$, respectively through seasons 2008/09, 2009/010 and their combined (Table 5).

In respect of the rest of the crosses which results from hybridization between moderately resistant or moderately susceptible with susceptible or resistance cultivars varied from positive to negative values, where some of these pass the significant level and the other did not reach to the level of significant (Table 5).

\section{Discussion}

In spite of the importance of the diseases resistance in faba bean crop, the progress made in 
resistance breeding to bean yellow mosaic virus (BYMV) disease in Vicia faba is rarely and it should be taken into consideration in the future breeding programme. Therefore, it is urgently to shed the light on the faba bean host resistance, since it is acknowledged that, resistant faba bean varieties could potentially form the basis of sustainable management strategies for the diseases (Asiedu, 1998). The selection of resistant varieties and continuous breeding programme for disease resistance appears to be the efficient means of controlling the disease considering (BYMV).

The results of this study clearly indicated that high genetic variation was observed from diallel technique, for bean yellow mosaic virus (BYMV) resistance. Using this technique, we showed that BPL 710 and Sakha 1 were highly resistant for BYMV and possess the highest negative values of GCA. Therefore, they could be considered good combiners for BYMV resistant and showing their aptitude to transmit the resistance trait at any future breeding program. Similar finding was reported in earlier by Shukla Et Al. (1978) and MA Et Al. (1995).

During survey periods, BYMV genotypes were found widely variations among seasons and locations. Where, genotypes $\mathrm{x}$ years interaction were significant, indicating the lack of stability across environments. Hence, this suggests that faba bean parents indicating crosses and also resulted hybrids must be evaluated in more than one year or environment to obtain a precise genetic information.

The ratio $\delta^{2} \mathrm{GCA} / \delta^{2} \mathrm{SCA}$ (more than unity) cleared greater role of additive effects in the genetic expressions, which controlling the resistance to bean yellow mosaic virus. However, it should be emphasized that $\delta^{2} \mathrm{GCA} / \delta^{2} \mathrm{SCA}$ ratio may not always project the true picture of the gene action for a character. This case is due to the deferential of parental ability to combine well with each other. These findings were so nearly with the results reported by Jones \& Smith (2005) during their studies on inheritance of hypersensitive resistance to Bean yellow mosaic virus in narrow-leafed lupin (Lupinus angustifolius). On the other hand, such combination depends considerably up complex interaction among genes and genotype by environment.

The non-predominance of neither GCA nor SCA was further reflected by non-significant correlation between the parental means and their GCA effects. This indicates that progeny performance cannot be determined from parental performance.

The significant parent female by parent male interaction also confirms the presence of non-additive components in the resistance of crosses/hybrids to bean yellow mosaic virus (BYMV). The ratio of additive variance to total genetic variance in a population is an indication of relative importance of both GCA and SCA in predicting progeny performance in resistance of Vicia faba to BYMV. The closer this ratio is to one the greater the chances of predicting progeny performance based on the general combining ability (GCA). Singh (1980) and Shankar Et Al. (2002) reported similar finding during their work on Vigna mungo and Lupinus angustifolius, respectively.

The significance of the contrast, parent vs. crosses justifying the separation of parents and 
crosses before the diallel analysis was done. The GCA and SCA sum of squares accounted for 33.14 and $26.46 \%$, respectively of the variation among the faba bean crosses. This demonstrated that both of additive and non-additives gene effects are also important in determining the expression of resistance to BYMV in Vicia faba even though the SCA contributed more.

Generally, it is worth to note that Bean yellow mosaic virus (BYMV) was more severe in fields with dense weed populations and it has been associated with other faba bean diseases incidence and severity. Some farmers do not see the need to weeds their faba bean fields, because the highest piece of herbicide and lowest income from the unit area. This leads to spread BYMV and decreases the resistance of cultivars.

From this findings the magnitude and sign of creating new genotypes have resistance genes for BYMV. our results also indicated that initial selection of parents for hybrid combination might probably could be largely be based on the disease reaction of the considering pathogen (BYMV). However, the significance of the maternal and reciprocal effects which detected suggested that the variation were also exhibited.

\section{Conclusions}

To our knowledge, this is the first study to report on the diallel analysis of bean yellow mosaic virus (BYMV) disease resistance in Vicia faba L. Significance implications for faba bean breeding programs that seek to incorporate resistance to bean yellow mosaic virus (BYMV). This is because in the diallel analysis, the additive effects and non-additive genetic effects are so desirable for the resistance to BYMV disease. Hence the progeny performance may be based on the parent performance per se. Therefore, it had emphasized the need to screen parents and crosses before their use in breeding suggesting that combining ability analysis based on progeny test data is useful in faba bean, Vicia faba breeding programme.

\section{References}

Abdalla M. M. A. \& Darwish D. S. (2002). Faba bean in Egypt to tolerance Orobanche: a review. Egypt J. Plant Breed., 6 (1): 143-160.

Allam E. K., Gamal Eldin A. S., El-kady M. A. S. \& Rizk Allah L. R. (1984). Biological differences between two bean yellow mosaic virus strains isolated from faba bean. Agric. Res. Rev. Cairo, 62: 314 - 305.

Anonymous (1997). Gene banks for 150 Gladiolus varieties developed. Agric News, III (3):139.

Asied R., Ngs.Y.C., Bai K.V., Ekanayake I. J. \& Wanyera N.M. (1998). Genetic Improvement. In Orkwor, G.C., R. Asiedu and I.J. Ekanayake, (Eds), Food Yams: Advances in Research. IITA and NRCRI Ibadan, Inigeria pp: 63-104.

Awaad H. A., Salem A. H., Mohsen A. M., Atia M. M., Hassan, E. E., Amer, M. I. \& Moursi A. M. (2005). Assessment of some genetic parameters for resistance to leaf miner, chocolate, rust and yield of faba bean in $\mathrm{F}_{3}$ and $\mathrm{F}_{4}$ generations. Egypt J. Plant Breed. 9 (1): 
$1-15$.

Bashir M. \& Hampton, R. O. (1996). Detection and identification of seed-borne viruses from cowpea (Vigna unguiculata L. Walp.) germplasm. Plant Pathology, 45: 54-58. doi:10.1046/j.1365-3059.1996.d01-97.x, http://dx.doi.org/10.1046/j.1365-3059.1996.d01-97.x

Bashir M., Ahmad Z. \& Ghafoor A. (2002). Cowpea aphid-borne mosaic potyvirus. stain a virus disease of broad beans (Vicia faba L.). Hort .Res., 5:13-18.

Beute M. K. (1970). Effect of virus infection on susceptibility to certain fungus diseases and $\begin{array}{lllll}\text { yield of } \quad \text { gladiolus. } & \text { Phytoathology, } & 60: 1809 & -1813 .\end{array}$ doi:10.1094/Phyto-60-1809http://dx.doi.org/10.1094/Phyto-60-1809

Bond D. A., Jellis G. J., Rowland G.G., Guen, L. D., Robertson, S. A. \& Khalil, L. (1994). Present status and future strategy in breeding faba beans (Vicia faba L.) for resistance to biotic and a biotic stresses. Euphytica, 73: 151-166. doi:10.1007/BF00027191, http://dx.doi.org/10.1007/BF00027191

Bouhassan A., Sadiki M. \& Tivoli B. (2004). Evaluation of a collection of faba bean (Vicia faba L.) genotypes originating from the Maghreb for resistance to chocolate spot (Botrytis fabae) by assessment in the field and laboratory. Euphytica, 135: 55-62. doi:10.1023/B:EUPH.0000009540.98531.4d,

http://dx.doi.org/10.1023/B:EUPH.0000009540.98531.4d

Cheng Y. \& Jones R.A.C. (2002). Thackray D. J. Deploying strain specific hypersensitive resistance to diminish temporal virus spread. Ann Appl Biol., 140:69 -79. doi:10.1111/j.1744-7348.2002.tb00158.x, http://dx.doi.org/10.1111/j.1744-7348.2002.tb00158.x

El-Badry M., Taha R. M., El-Dougdoug K. A. \& Gamal-Eldin H. (2006). Induction of systemic resistance in faba bean (Vicia faba L.) to bean yellow mosaic potyvirus (BYMV) via seed bacterization with plant growth promoting Rhizobacteria. J Plant Dis Prot, 113 (6):247-251. Cockerham G. (1970). Genetic studies on resistance to potato viruses X and Y. Heredity 25:309-348.

El-Beshery, E. K. F. (1999). Pathological studies on some viruses infecting legume plants in Ismailia Governorate. Thesis Mc. s.' Agricultural Botany Department, Faculty of Agriculture, Suez Canal University, Ismailia, Egypt, Pp., 122.

El-Bramawy M. A. S. \& Abdul Wahid O. A. (2005). Faba bean sources of resistance to chocolate and spot diseases, earliness and seed yield. The $7^{\text {th }}$ ACSS Conference, 5-9 Sept., Uganda. Vol: 7: 359-562.

El-Bramawy M. A. S. \& Shaban W. I. (2010). Effects of potassium fertilization on agronomic characters and resistance to chocolate spot and rust diseases in faba bean. Tunisian Journal of Plant Protection. Vol. 5, No. 2, 131-150.

El-Hosary A. A., Bastawisy M. H. \& Tageldin M. H. (1998). Heterosis and combining ability for yield and its components, earliness, total shedding and resistance to diseases and insects 
in faba bean (Vicia faba L.). In: Proc. $8^{\text {th }}$ Conf. Agronom., Suez Canal Univ., Ismailia, Egypt, 28-29 Nov. 1998: 268-279.

El-Tahlawy M., Rizkallah L. R. \& Abdelkader H. S. (2005). Field Evaluation of Different Faba Bean Genotypes for Seed Transmission Ability of Some Viruses Using Serological Techniques. Egyptian J. Virol. 2, 225-237.

Griffing B. (1956). Concepts of general and specific combining ability in relation to diallel crossing systems. Aust. J. Biol. Sci., 9: 463-493.

Hassan A. A. (1996). Eldar Production of vegetable crops. ELarabia Lil Nashr Wa Eltawzia. $710 \mathrm{pp}$.

Hawtin G.C. \& Hebblethwaite P. D. (1983). Background and history of faba beans production. In: The faba beans (Vicia faba), a basis for improvement Hebblethwaite, P.D. (ed.), pp. 3-22. Butterworths, London.

Hobbs H. A., Reddy, D. V., Rasjeshwari R. \& Reddy, A. S. (1987). Use of direct antigen coating and protein a coating ELISA procedures for detection of three peanut viruses. Plant diseases, 71: 747-749. doi: 10.1094/PD-71-0747, http://dx.doi.org/10.1094/PD-71-0747

Ibrahim A. A. \& Nassib A. M. (1979). Screening for disease resistance in broad beans (Vicia faba) in Egypt. Fabis Newsletter 1, 25.

Khalil, S. A. and Erskine, W. (2001). Combating disease problems of grain legumes in Egypt. Grain Legumes, a32 (2): 24-26.

Khatab, Eman A. H. (2002). Recent techniques to study some broad bean viral diseases. Ph. D Thesis, Fac. of Agricuture. Zagazig University. PP.135.

Kang M. S. (1994). Applied quantitative genetics. M. S. Kang Publisher Baton Rouge, LA., pp: 194.

Jones R. A. C. (1997). Bean yellow mosaic virus in lupins. Western Australian Journal of Agriculture, Fourth Series, 38:42-48.

Jones R.A.C. (2004). Using epidemiological information to develop effective integrated virus disease management stra tegies. Virus Res, 100:5-30.

R. A. C. (2005). Aphid-borne viruses in lupin stands under four different Jones Patterns of spread of two non-persistently infection scenarios. Annals of Applied Biology, 146:337- 357.

Jones R. A. C. \& Mclean G. D. (1989). Virus diseases of lupins. Annals of Applied Biology 114:609-937.

Jones R. A.C. \& Smith L. J. (2004). Inheritance of hypersensitive resistance to Bean yellow mosaic virus in narrow-leafed lupin (Lupinus angustifolius). Annals of Applied Biology, 146:539-543.

Jones R. A .C. (2005). Aphid-borne viruses in lupin stands under four different Patterns of spread of two non-persistently infection scenarios. Annals of Applied Biology, 146:337- 357. 
Ma G., Chen P., Buss G. R. \& Tolin S. A. (1995). Genetic characteristics of two genes for resistance to soybean mosaic virus in PI486355 soybean. Theoretical and Applied Genetics, 91:907-914.

Mahgoub H. A., Wipf-Scheibel C., Delecolle B., Pitrat M., Dafalla G., \& Lecoq H. (1997). Melon rugose mosaic virus: characterization of an isolate from Sudan and seed transmission in melon. Plant Dis., 81:656-60.

Mwanamwenge J., Loss S. P., Siddique k. H. M. \& Cocks, P. (1998). Growth, seed yield and water use of faba bean (Vicia faba L.) in a short-season Mediterranean-type environment. Aust J Exp Agric., 38:171-80.

Radwan D. E. M., LU G., Fayez K. A., Mahmoud S.Y. \& Hamad A. (2008). Protective action of salicylic acid against bean yellow mosaic virus infection in Vicia faba leaves. Journal of Plant Physiology, 165, 845-857.

Shankar M., Sweetingham M. W. \& Cowling W. A. (2002). Identification of alleles at two loci controlling resistance to phomopsis stem blight in narrow-leafed lupin (Lupinus angustifolius). Euphytica, 125:35 - 44.

Singh, B. B. \& Malick A. S. (1978). Inheritance of yellow mosaic in Soybean. Indian J. Genet. Plant Breed, 38, 258-261.

Singh, D. P. (1980). Inheritance of resistance to yellow mosaic virus in blackgram, Vigna mungo L. Hepper. Theor. Appl. Genet., 57, 233-235.

Shukla G. P., Pandya, B. P. \& Singh D. P. (1978). Inheritance of resistance to yellow mosaic in mungbean. Indian J. Genet. Plant Breed, 38, 357-360.

Sidaros S. A., El-kewey S. A., Eman A. H. Khattab \& El-sharkawy, M. M. (2006). Purification, serology and prevalence of Broad bean stain como virus (BBSV) and Cowpea aphid borne mosaic Potyvirus (CABMV). Egyptian J.Virol., 3(1), 71-88.

Singh R. K. \& Chaudhary B. D. (1977). Biometrical methods in quantitative genetic analysis. Kalyani Publisher. New Delhi, India.

Tivoli B. P., Berthelem J., Guen L. E. \& Onfroy C. (1988). A study of the performance of certain faba bean genotypes in relation to Botrytis fabae and Ascochyta fabae in France. FABIS Newsletter, 21: 36-39.

Zhang, Z. \& Kang S. K. (1997). A SAS Program for Griffing's Diallel Analyses. Agron. J., 89: 176-182.

Yang, X., Llangyi, K. \& Tien, P. (1996). Resistance of tomato infected with cucumber mosaic virus satellite RNA to potato spindle tuber viroid. Ann Appl Biol, 129: 543-51. doi:10.1111/j.1744-7348.1996.tb05775.x,

http://dx.doi.org/10.1111/j.1744-7348.1996.tb05775.x 
Table 1. Faba bean genotypes name, pedigree, earliness (days to 50\% flowering), seed yield (g/plant).

\begin{tabular}{|c|c|c|c|c|c|}
\hline No. & $\begin{array}{l}\text { Parents } \\
\text { Cultivars }\end{array}$ & Pedigree & Earliness & $\begin{array}{l}\text { Seed yield } \\
\text { (g/plant) }\end{array}$ & Description symptoms \\
\hline $\mathrm{P} 1$ & Tribe White & $\begin{array}{l}\text { Individual plant from } \\
\text { sudanese selection }\end{array}$ & 54.26 & 31.58 & $\begin{array}{c}\text { Yellow and Leaf roll in upper } \\
\text { leaves }\end{array}$ \\
\hline $\mathrm{P} 2$ & Giza 3 & Cross (Giza 1 x N A 29) & 50.23 & 23.62 & $\begin{array}{r}\text { Savers Mosaic, Yellow and } \\
\text { Leaf roll in upper leaves }\end{array}$ \\
\hline P3 & Giza714 & $\begin{array}{c}\text { Cross }(462 \mathrm{~B} 1 \\
908 / 83 / 503 / 453 / 83\end{array}$ & 52.12 & 31.02 & $\begin{array}{l}\text { Mosaic, Yellow and Leaf roll } \\
\text { in upper leaves }\end{array}$ \\
\hline $\mathrm{P} 4$ & Giza 429 & $\begin{array}{l}\text { Individual plant selection } \\
\text { from Giza } 402\end{array}$ & 52.10 & 33.98 & Light Leaf roll in upper leaves \\
\hline P5 & Sakha 1 & $\begin{array}{c}\operatorname{Cross}(7161924 / 88 x \\
620 / 283 / 81)\end{array}$ & 49.21 & 38.59 & $\begin{array}{c}\text { Yellow and Leaf roll in upper } \\
\text { leaves }\end{array}$ \\
\hline P6 & BPL 710 & $\begin{array}{l}\text { NA, Introduce from } \\
\text { Clombia. }\end{array}$ & 48.02 & 37.41 & Resistant \\
\hline
\end{tabular}

Table 2. Interaction between faba bean parental plants and BYMV with scale rating.

\begin{tabular}{|c|c|c|c|c|c|}
\hline No. & $\begin{array}{c}\text { Parents } \\
\text { Cultivars }\end{array}$ & $\begin{array}{c}\text { S/T } * \\
\text { Replicates }\end{array}$ & $\begin{array}{c}\text { Percentage of } \\
\text { infection }\end{array}$ & $\begin{array}{c}\text { Percentage of disease } \\
\text { severity (DS \%). }\end{array}$ & $\begin{array}{c}\text { Interaction } \\
\text { Category** }\end{array}$ \\
\hline P1 & Tribe White & $20 / 30$ & $66.67 \%$ & $33.33 \%$ & Moderately Tolerance \\
\hline P2 & Giza 3 & $25 / 30$ & $83.33 \%$ & $83.33 \%$ & Susceptible \\
\hline P3 & Giza714 & $22 / 30$ & $73.33 \%$ & $55.00 \%$ & Moderately Tolerance \\
\hline P4 & Giza 429 & $18 / 30$ & $60.00 \%$ & $15.00 \%$ & Tolerance \\
\hline P5 & Sakha 1 & $19 / 30$ & $63.33 \%$ & $48.33 \%$ & Moderately Tolerance \\
\hline P6 & BPL 710 & - & $0.00 \%$ & $0.00 \%$ & Resistance \\
\hline
\end{tabular}

$*=$ Number of symptomatic plant (S) / Total number of tested plants $(\mathrm{T})$.

** 0-10 = Resistance, $10.10-30=$ Tolerance, $30.10-60=$ Moderately Tolerance, $60.10-90=$ Susceptible and $90.10-100=$ Highly Susceptible. 
Table 3. Diallel analysis of variance for bean yellow mosaic virus (BYMV) of faba bean.

\begin{tabular}{|c|c|c|c|c|}
\hline \multirow[b]{2}{*}{$\begin{array}{c}\text { Sources of } \\
\text { variation }\end{array}$} & \multirow{2}{*}{$\begin{array}{l}\text { Degree } \\
\text { of } \\
\text { freedom }\end{array}$} & \multicolumn{3}{|c|}{ Mean squares } \\
\hline & & $2008 / 09$ & $2009 / 010$ & combined \\
\hline Reps & 2 & $9.31 *$ & $8.82 *$ & 10.30 \\
\hline Years (Y) & 1 & - & - & $24.12 * *$ \\
\hline Reps (R) & 4 & - & - & $15.90^{*}$ \\
\hline Genotypes (G) & 35 & $267.11^{* *}$ & $149.80 * *$ & $95.57 * *$ \\
\hline Parent (P) & 5 & $136.23 * *$ & $102.80 * *$ & $58.45 * *$ \\
\hline Cross (C) & 29 & $142.84 * *$ & $150.03 * *$ & $91.49 * *$ \\
\hline GCA & 5 & $276.71 * *$ & $229.58 * *$ & $270.33 * *$ \\
\hline SCA & 18 & $93.17^{* *}$ & $110.07^{*}$ & $104.27 * *$ \\
\hline$\delta 2 \mathrm{GCA} / \delta 2 \mathrm{SCA}$ & - & 2.97 & 2.09 & 2.59 \\
\hline Maternal & 5 & $128.03 * *$ & $118.95 * *$ & $107.13 * *$ \\
\hline Reciprocal & 18 & $66.13^{* *}$ & $53.43 * *$ & $21.70 * *$ \\
\hline $\mathrm{P} \times \mathrm{C}$ & 1 & $56.67 * *$ & $40.27 * *$ & $26.28 *$ \\
\hline $\mathrm{C} \quad \mathrm{X} \quad \mathrm{Y}$ & 29 & - & - & $33.03 * *$ \\
\hline GCA $\times$ Y & 5 & - & - & $30.40 * *$ \\
\hline SCA $x \quad Y$ & 18 & - & - & $84.38 * *$ \\
\hline REC $\mathrm{x} Y$ & 18 & - & - & $16.55^{*}$ \\
\hline $\begin{array}{lll}M & \mathrm{X} & \mathrm{Y}\end{array}$ & 5 & - & - & $43.15 * *$ \\
\hline Error pooled & & 11.37 & 22.62 & 16.99 \\
\hline
\end{tabular}

*, ** Significantly different from zero at 0.05 and 0.01 probability levels, respectively.

Table 4. Estimates of general combining ability (GCA) effects for $6 \times 6$ diallel analysis of resistance to bean yellow mosaic virus (BYMV) of faba bean.

\begin{tabular}{|c|c|c|c|c|c|c|c|}
\hline \multirow{2}{*}{ No. } & \multirow{2}{*}{ Parental } & \multicolumn{2}{|c|}{$2008 / 09$} & \multicolumn{2}{c|}{$2009 / 010$} & \multicolumn{2}{c|}{ Combined } \\
\cline { 3 - 8 } & & LSM*** & GCA & LSM & GCA & LSM & GCA \\
\hline P1 & Tribe White & 9.17 & $-1.89^{*}$ & 8.99 & $1.30^{*}$ & 9.08 & $1.91^{*}$ \\
\hline P2 & Giza 3 & 11.6 & $2.71^{* *}$ & 9.89 & $3.65^{* *}$ & 10.75 & $4.11^{* *}$ \\
\hline P3 & Giza714 & 18.12 & 1.09 & 16.08 & $1.31^{*}$ & 17.10 & 0.13 \\
\hline P4 & Giza 429 & 13.28 & $3.64^{* *}$ & 15.09 & 1.04 & 15.69 & $1.11^{*}$ \\
\hline P5 & Sakha 1 & 7.12 & $-1.64^{*}$ & 6.37 & $-2.16^{* *}$ & 6.75 & $-3.08^{* *}$ \\
\hline P6 & BPL 710 & 6.34 & $-3.91^{* *}$ & 5.19 & $-5.14^{* *}$ & 5.77 & $-4.18^{* *}$ \\
\hline \multicolumn{3}{|c|}{ SE (gi - gj) } & \multicolumn{3}{|c|}{2.95} & & \multicolumn{2}{c}{2.87} \\
\hline
\end{tabular}

* Significantly different from zero at 0.05 and 0.01 probability levels, respectively.* ,*

*** LSM $=$ least square means 
Table 5. Estimates of specific combining ability (SCA) effects and reciprocal effects for $6 \times 6$ diallel analysis of Resistance to bean yellow mosaic virus (BYMV) of faba bean.

\begin{tabular}{|c|c|c|c|c|c|c|c|}
\hline \multirow[t]{2}{*}{ Crosses } & \multicolumn{2}{|c|}{$2008 / 09$} & \multicolumn{2}{|c|}{$2009 / 010$} & \multicolumn{2}{|c|}{ Combined } & \multirow[t]{2}{*}{ Effects } \\
\hline & $\mathrm{LSM}^{* * *}$ & SCA & LSM & SCA & LSM & SCA & \\
\hline P1 x P2 & 16.95 & $6.31 * *$ & 20.39 & $3.87^{*}$ & 18.67 & $5.11 * *$ & SCA \\
\hline P1 x P3 & 11.32 & 1.69 & 14.69 & $2.19^{*}$ & 13.01 & $3.00^{*}$ & SCA \\
\hline P1 x P4 & 10.30 & $2.47^{*}$ & 11.09 & 1.39 & 10.69 & 1.08 & SCA \\
\hline P1 x P5 & 7.30 & $4.10 * *$ & 6.98 & $5.11 * *$ & 7.14 & $7.39 * *$ & SCA \\
\hline P1 x P6 & 5.21 & $-3.01 *$ & 7.97 & $-3.28 *$ & 6.59 & $-3.89 * *$ & SCA \\
\hline $\mathrm{P} 2 \times \mathrm{P} 3$ & 19.32 & $6.21 * *$ & 22.68 & $8.14^{* *}$ & 21.00 & $4.59 * *$ & SCA \\
\hline P2 x P4 & 17.30 & -1.64 & 18.21 & $2.00^{*}$ & 17.76 & $-3.01 *$ & SCA \\
\hline P2 x P5 & 15.28 & $4.11 * *$ & 13.90 & $6.17 * *$ & 14.59 & $5.12 * *$ & SCA \\
\hline $\mathrm{P} 2 \times \mathrm{P} 6$ & 6.31 & $2.84^{*}$ & 12.01 & $3.14^{*}$ & 9.16 & $2.61 *$ & SCA \\
\hline P3 x P4 & 9.31 & 1.36 & 11.67 & 1.67 & 10.49 & $2.11^{*}$ & SCA \\
\hline P3 x P5 & 7.79 & $4.09 * *$ & 7.10 & $6.33 * *$ & 7.45 & $5.29 * *$ & SCA \\
\hline P3 x P6 & 4.99 & $-3.60 *$ & 6.30 & $-3.54 *$ & 5.65 & $-4.18 * *$ & SCA \\
\hline $\mathrm{P} 4 \times \mathrm{P} 5$ & 9.79 & 0.97 & 12.39 & 1.22 & 11.09 & 0.37 & SCA \\
\hline P4 x P6 & 5.64 & -1.62 & 5.10 & $-2.33^{*}$ & 5.37 & $-2.41 *$ & SCA \\
\hline P5 x P6 & 3.68 & -1.87 & 4.23 & -1.08 & 5.96 & -1.99 & SCA \\
\hline $\mathrm{P} 2 \times \mathrm{P} 1$ & 20.03 & 1.61 & 23.19 & $2.51^{*}$ & 21.61 & -1.87 & Recip \\
\hline P3 x P1 & 11.63 & $2.36^{*}$ & 9.36 & 1.94 & 10.49 & $2.23 *$ & Recip \\
\hline $\mathrm{P} 3 \times \mathrm{P} 2$ & 14.69 & $2.98^{*}$ & 13.98 & 1.99 & 14.34 & $3.01 * *$ & Recip \\
\hline P4 x P1 & 8.88 & $4.32 * *$ & 7.39 & $3.68 * *$ & 8.14 & $5.06 * *$ & Recip \\
\hline P4 x P2 & 15.97 & 2.01 & 12.98 & 1.38 & 14.48 & 1.84 & Recip \\
\hline P4 x P3 & 11.10 & $3.14^{*}$ & 9.89 & $2.99 *$ & 10.49 & $2.31^{*}$ & Recip \\
\hline P5 x P1 & 7.39 & $4.98 * *$ & 6.32 & $4.19 * *$ & 6.89 & $5.16^{* *}$ & Recip \\
\hline P5 x P2 & 15.39 & $2.58 *$ & 17.97 & $6.07 * *$ & 16.68 & $4.36^{* *}$ & Recip \\
\hline P5 x P3 & 9.07 & -1.68 & 10.20 & 1.97 & 9.64 & -1.91 & Recip \\
\hline P5 x P4 & 6.15 & 0.98 & 5.38 & 1.71 & 5.77 & 1.67 & Recip \\
\hline P6 x P1 & 7.19 & $-6.11 * *$ & 8.10 & $-5.98 * *$ & 8.70 & $-6.19 * *$ & Recip \\
\hline P6 x P2 & 8.31 & $-2.67^{*}$ & 7.08 & $-3.58 * *$ & 7.70 & $-4.42 * *$ & Recip \\
\hline P6 x P3 & 5.99 & $-4.32 * *$ & 4.29 & $-6.87 * *$ & 5.14 & $-10.18^{* *}$ & Recip \\
\hline P6 x P4 & 6.13 & $-3.91 * *$ & 5.33 & $-5.48 * *$ & 5.73 & $-6.11 * *$ & Recip \\
\hline P6 x P5 & 4.21 & $-6.68 * *$ & 3.94 & $-4.69 * *$ & 4.08 & $-5.67 * *$ & Recip \\
\hline SE (sii) & - & 4.31 & - & 3.76 & - & 2.61 & - \\
\hline SE (sij) & - & 2.01 & - & 1.59 & - & 1.69 & - \\
\hline SE (sii-sjj) & - & 4.26 & - & 4.65 & - & 3.91 & - \\
\hline SE (ii-skj) & - & 4.96 & - & 5.14 & - & 4.11 & - \\
\hline SE (ij-skj) & - & 5.24 & - & 4.96 & - & 3.79 & - \\
\hline
\end{tabular}

P1= Tribe White, P2= Giza 3, P3= Giza714, P4 = Giza 429, P5 = Sakha 1 and P6 = BPL 710

*,**Significantly different from zero at 0.05 and 0.01 probability levels, respectively.

*** LSM $=$ least square means. 